\title{
НАУЧНАЯ ЖИЗНЬ
}

DOI: $10.18384 / 2310-7278-2021-4-112-115$

\section{ДУХОВНЫЕ ПОДВИЖНИКИ ОБ УЧИТЕЛЬСКОМ ПРИЗВАНИИ}

\section{Батурова Т.К.}

Московский государственный областной университет

141014, Московская обл., г. Мытищи, ул. Веры Волошиной, д. 24, Российская Федерация

\section{SPIRITUAL ASCETICS ABOUT THE TEACHER'S CALL}

\section{T. Baturova \\ Moscow Region State University \\ 24 Very Voloshinoi ul., Mytishchi 141014, Moscow Region, Russian Federation}

С 2001 г. отмечается на факультете русской филологии МГОУ День славянской письменности и культуры, пришедший сюда благодаря усилиям покойной Клавдии Анатольевны Войловой. Сначала скромный и малочисленный, теперь он стал важным, большим, ожидаемым событием на факультете. Возглавляемый деканом, Ольгой Викторовной Шаталовой, этот праздник охватывает и преподавателей, и студентов: научную информацию сменяют студенческие сценки, музыкальные номера, выступления ансамбля «Виноградие». Но есть в этом радостном событии особая тема: День славянской письменности и культуры заставляет серьёзно задуматься о роли школьного учителя и вузовского преподавателя, ведь именно они являются главными носителями письменности и культуры в современной жизни. Поистине высоко их призвание!

Языковед, писатель Василий Давыдович Ирзабеков в книге «Тайна русского слова» говорит о смысле слова «призвание» и отмечает, что «на фоне “тотальной жаргонизации” речи возвышается это величественное слово, имеющее Божественный исток - “призывание”. Встаёт вопрос: Кем и к чему мы призываемся? Каждому человеку очень важно различить в людском многоголосии зов Призывающего его!» [1, с. 140]. Помогают это сделать духовные подвижники, которых называют «земными ангелами и небесными человеками». Кто-то из них размышлял об учительском призвании, видя высокий смысл этой профессии, кто-то сам был преподавателем. Но все они стали истинными духовными наставниками для своих современников, таковыми являются они и для нас. Их суждения о главном деле нашей жизни важнее всех официальных рекомендаций и установок.

У преподобного Серафима Саровского есть удивительные слова о том, что обучение других - это особое, Божественное поручение. Он строго наставлял своего келейника отца Павла и говорил: «Себя самого знай, а учить никогда никого не смей: не дал Бог тебе этого дара...» [6, с. 325]. Значит, право учить других даёт не диплом педагогического вуза и даже не аттестат доцента или профессора, а совсем иная Инстанция. Преподобный Серафим не был профессиональным педагогом, но стал великим учителем радости для многих приходящих к нему. «Радость моя», «сокровище моё» - с такими словами обращался он к людям, и души человеческие оттаивали, согревались. Поразительным было умение отца Серафима посмотреть духовными очами на детское поведение, понять состояние ребёнка, и определялось это умение любовью к человеку. Любовью исправлял

(c) СС ВY Батурова Т. К., 2021. 
старец непокорных и шаловливых детей. Он советовал родителям в первую очередь развивать душу ребёнка, а уж потом заботиться о светском образовании, ибо, по слову Спасителя, «ищите же прежде Царства Божия и правды Его, и это всё приложится вам» (Евангелие от Матфея 6: 33).

Светлый образ старца Серафима покорил не одно детское сердце, отложился в сокровенных глубинах памяти, а потом воплотился в воспоминаниях уже взрослых людей. С. А. Нилус в книге «Великое в малом» приводит рассказ о первой поездке в Саров вдовы, Марии Александровны Мотовиловой, вместе с маленьким сыном Николенькой, который впоследствии станет «служкой Божией Матери и Серафима». Было это в 1816 г., когда мальчику шёл восьмой год. Батюшка Серафим тогда только что вышел из затвора и принимал приходивших к нему за помощью и советом. Одними из первых его посетителей и стали Мотовиловы. Ребёнок был поражён убранством кельи, видом старца. С. А. Нилус пишет: «Обстановка кельи поразила мальчика настолько, что уже спустя много лет он помнил её во всех подробностях. Особенно его детское воображение было поражено обилием горящих свечей в семи больших подсвечниках перед иконой Божией Матери» [5, с. 11].

Детская память не сохранила речей старца, но сберегла один удивительный эпизод: «Скучно стало мальчику, привыкшему резвиться на деревенской свободе, и, пока мать внимала беседе богомудрого Старца, он стал бегать по келье, насколько позволяла её обстановка. Мать с упрёком его остановила. Но батюшка на её упрёк ребёнку возразил:

- С малюткой Ангел Божий играет, матушка! Как можно ребёнка останавливать в его беспечных играх... Играй, играй, деточка! Христос с тобой!

Эти слова, полные кротости и отеческой ласки, Мотовилов помнил всю жизнь» [5, c 13].

Преподобный Амвросий Оптинский (в миру - Александр Михайлович Гренков) был преподавателем Липецкого духовного училища, служил и домашним учителем. В молодости - душа компании, весёлый, жизнерадостный человек. Но однажды этот «обычный» учитель, гуляя в лесу под Липецком, услышал в журчании ручья призыв: «Хвалите Бога! Храните Бога!» [4, c. 164]. И это изменило его жизнь. Спустя многие годы к нему, немощному, больному оптинскому старцу приезжали молодые, богатые, здоровые люди, просили о помощи, спрашивали, как жить. И он, глядя на приходящих своими ясными, лучистыми глазами, учил: «Живи попроще, живи попроще». При этом пояснял: «Где просто, там ангелов со сто, а где мудрёно - там ни одного» [3, с. 260]. И ещё: «Мы должны жить на земле так, как колесо вертится, чуть только одной точкой касается земли, а остальными непременно стремится вверх» [3, с. 169].

Духовные наставления преподобного Амвросия утешили и успокоили не одного человека. Ф. М. Достоевский, К. Н. Леонтьев, В. С. Соловьёв, Н. Н. Страхов, А. К. Толстой, А. Н. Апухтин, Е. Поселянин стали учениками великого старца.

Святой праведный Иоанн Кронштадтский - наш коллега: 25 лет преподавал Закон Божий в учебных заведениях Кронштадта и считал, что воспитание и обучение детей - дело «великое и многотрудное». Остро ощущал он учительскую ответственность и говорил учителям: «Граждане вверяют нашему попечению и руководству то, что для них есть самого драгоценнейшего в жизни - детей своих, эти как бы сердца свои, и их взоры с надеждою устремлены на нас». А ещё спрашивал: «Что мы хотим сделать из наших юношей? Всезнающих или многознающих учёных мужей?» И отвечал: «Слишком этого недостаточно. Можно и весьма много знать, быть весьма умным человеком и в то же время, увы, быть негодным человеком и вредным членом общества». Потом пояснял: «Истинно полезными христианскому обществу членами могут быть только воспитанные в христианских по- 
нятиях, правилах, обычаях добрые сыны Православной Церкви» [2, с. 87-88].

А вот мысли отца Иоанна о сути образования: «Душа человеческая по природе проста и всё простое легко усвояет себе, обращает в свою жизнь и сущность, а все хитросплетенное отталкивает от себя, как не свойственное её природе, как бесполезный сор. Мы все учились. Что же осталось в нашей душе из всех наук? Что врезалось неизгладимо в сердце и память? Не с детскою ли простотою преподанные истины? Не сором ли оказалось всё, что было преподано искусственно, безжизненно? Не напрасно ли потрачено время на слишком мудрые уроки? Так, - это всякий из нас испытал на себе» $[2$, с. 71].

Постоянно звучит у отца Иоанна мысль о том, что надо развивать, прежде всего, не ум, а душу ребёнка. И это созвучно с суждениями священнослужителя Сербской православной церкви преподобного Иустина Поповича, который позднее скажет: «С разумом, но без доброты и нежности человек - это законченный демон» ${ }^{1}$.

Совсем недавно ушедший из жизни протоиерей Димитрий Смирнов служил председателем Патриаршей комиссии по вопросам семьи, материнства и детства и считал преподавательскую работу, выполняемую со всею душой, святым делом, видел в ней взаимодействие человеческих душ. Он утверждал, что становиться педагогами должны не те, кому не удалось по- ступить в престижные вузы, а лучшие из лучших. А ещё говорил: «Школа должна готовить к жизни, но жизнь - это семья, а не раскрытие себя и самореализация». И заключал, прямо обращаясь к нам: «А учителям я бы дал два совета - любить детей больше, чем самого себя, и быть профессионалом своего дела» ${ }^{2}$.

Заключить эти искренние и мудрые рассуждения духовных подвижников об учительском призвании хочется строчками из хорошей песни на слова Л. И. Ошанина, где звучит голос настоящего учителя:

Понимаешь, мама, я учитель.

Видишь, я вхожу, бледнея, в класс.

Это мне решили поручить их,

Сорок душ и восемьдесят глаз.

Учитель...

Сколько надо любви и огня,

Чтобы слушали,

Чтобы верили,

Чтобы помнили люди меня. $* * *$

Может, будет трудно, небогато, Буду жить, свой выбор не браня.

Понимаешь, ведь мои ребята -

Это продолжение меня.

Учитель...

Сколько надо любви и огня,

Чтобы слушали,

Чтобы верили,

Чтобы помнили люди меня ${ }^{3}$.

\section{ЛИТЕРАТУРА}

1. Ирзабеков В. Д. Тайна русского слова. Заметки нерусского человека. М.: Даниловский благовестник, 2007. 200 с.

2. Источник живой воды. Жизнеописание святого праведного отца Иоанна Кронштадтского / сост. Н. И. Большаков. СПб.: Царское дело, 1995. 855 с.

3. Концевич И. М. Оптина пустынь и её время. Минск: Изд-во Белорусского Экзархата, 2006. 576 с.

4. Котельников В. А. Православные подвижники и русская литература. На пути к Оптиной. М.: Прогресс-плеяда, 2002. 384 с.

5. Нилус С. А. Великое в малом // Нилус С. А. Полн. собр. соч.: в 6 т. Т. 1. М.: Паломникъ, 1999. С. 11-13.

6. Преподобный Серафим Саровский в воспоминаниях современников. М.: Ковчег, 2003. 416 с.

1 Попович Иустин. Серна в потерянном рае [Электронный pecypc]. URL: https://koppel.pro/guest/serna-vpoterannom-rae-8404 (дата обращения: 08.03.2021).

2 Смирнов Д., прот. Как я потерялся первого сентября [Электронный pecypc]. URL: https://www.pravmir.ru/1sentyabrya-kak-ya-poteryalsya-i-drugie-istorii1 (дата обращения: 08.03.2021).

3 Ошанин Л. И. Учитель [Электронный ресурc]. URL: https://www.stihi.ekimovka.ru/index.php?option=com content\&view=article\&id=562:1-oshanin-uchitel\&catid=23\&Itemid=149 (дата обращения: 08.03.2021). 


\section{REFERENCES}

1. Irzabekov V. D. Taina russkogo slova. Zametki nerusskogo cheloveka [Mystery of the Russian Word. Notes of Non-Russian Person]. Moscow, Danilovskij blagovestnik Publ., 2007. 200 p.

2. Bolshakov N. I., comp. Istochnik zhivoi vody. Zhizneopisanie svyatogo pravednogo otca Ioanna Kronshtadtskogo [A Source of Living Water. Biography of the Holy Righteous Father John of Kronstadt]. St. Petersburg, Tsarskoye delo Publ., 1995. 855 p.

3. Kontsevich I. M. Optina pustyn' i ee vremya [Optina Desert and Is Era]. Minsk, Belorussian Exarchate Publ., 2006. 576 p.

4. Kotel'nikov V. A. Pravoslavnye podvizhniki i russkaya literatura. Na puti $k$ Optinoi [Orthodox Ascetics and Russian literature. On the Way to Optina]. Moscow, Progress-pleyada Publ., 2002. 384 p.

5. Nilus S. A. [Great in Small Thing]. In: Nilus S. A. Poln. sobr. soch. T. 1 [Collected works. Vol. 1]. Moscow, Palomnik Publ., 1999, pp. 11-13.

6. Prepodobnyi Serafim Sarovskii v vospominaniyakh sovremennikov [Reverend Seraphim of Sarov in the Memoirs of His Contemporaries]. Moscow, Kovcheg Publ., 2003. 416 p.

\section{ИНФОРМАЦИЯ ОБ АВТОРЕ}

Батурова Татьяна Константиновна - доктор филологических наук, профессор кафедры русской классической литературы Московского государственного областного университета; e-mail: baturova.t@yandex.ru

\section{INFORMATION ABOUT THE AUTHOR}

Tatyana K. Baturova - Dr. Sci. (Philology), Prof., Department of the Russian Classical Literature, Moscow Region State University;

e-mail: baturova.t@yandex.ru

\section{ПРАВИЛЬНАЯ ССЫЛКА НА СТАТЬЮ}

Батурова Т. К. Духовные подвижники об учительском призвании // Вестник Московского государственного областного университета. Серия: Русская филология. 2021. № 4. С. 112-115.

DOI: $10.18384 / 2310-7278-2021-4-112-115$

\section{FOR CITATION}

Baturova T. K. Spiritual Ascetics about The Teacher's Call. In: Bulletin of Moscow Region State University. Series: Russian philology, 2021, no. 4. pp. 112-115.

DOI: 10.18384/2310-7278-2021-4-112-115 